\title{
The Influence of Perception Regarding Startup Towards Career Choices in Startup Field on Generation Y and Generation Z College Students in Bandung City
}

\author{
Sarah Sentika $^{1)}$, Rivaldi Arissaputra ${ }^{2 *}$ \\ 1) Faculty of Economy and Humanity, 'Aisyiyah Bandung University \\ 2) Faculty of Economy and Humanity, 'Aisyiyah Bandung University \\ *Coresponding Author \\ Email : $\underline{\text { sarahsentika@unisa-bandung.ac.id }}$
}

\begin{abstract}
The importance of the development of startups in Indonesia to help the digital economy provides opportunities for generation $Y$ and $Z$ students to contribute considering that there are similarities in the work scope between startups and generations $Y$ and $Z$. However, their tendency to change jobs is a challenge in making choices. suitable career. The purpose of this study was to examine and analyze the effect of perceptions about startups on career choices in the startup field for generation $Y$ and $Z$ students in Bandung. The sample in this study as many as 168 respondents were taken using the accidental sampling method and processed using SmartPLS 3. The results showed that in generation $Y$ and generation $Z$ perceptions about sta rtups had a significant effect on career choices in the startup field, but if they were differentiated by group, the generation $Y$ perception about startups has an influence on career choices in the startup field, while in the generation $Z$ group perceptions about startups have no effect on career choices in the startup field
\end{abstract}

Keywords: Perception, Career Options, Startup, Generation Y, Generation Z

\section{INTRODUCTION}

The rapid development of information technology in the current digital era has led to creative ideas in business development, including building startup companies. Startup company is a company with its business operations digitally and very fast movement and populated by fewer than 20 employees (Suwarno, 2017). The term startup is often associated with technology, the web, the internet, and the like (Ayu, 2017). According to Bekraf (2018), until 2018 the number of startups in Indonesia reached 992 companies, but startups from West Java were quite small, only 44 companies. Bandung as the capital of West Java province which has a role as an economic and business center was designated as a creative city by UNESCO in 2015, therefore it is hoped that Bandung can increase the number of startups to support Indonesia's digital economy.

The need for human resources to improve startups in Bandung provides opportunities, especially for students who will later choose a career. Students at the current D3, S1 and S2 education levels are categorized into generation $\mathrm{Y}$ and generation $\mathrm{Z}$ where according to Reeves \& Oh (2008) generation Y was born in 1981-1995 while generation Z was over 1995. The thing that distinguishes generation $\mathrm{Z}$ from another generation is the mastery of information technology, besides that for generation $\mathrm{Z}$ technology and information are already part of their lives (Bencsik \& Machova, 2016). This indicates that generations $\mathrm{Y}$ and $\mathrm{Z}$ have similar characteristics with startup companies considering that according to Ayu (2017) startup companies are identical and always related to technology, the web, the internet, and the like. Based on this, Generation Y and Generation Z should be interested in a career in startup 
considering the character startup that fits their personality. Every individual must have a plan in every decision that will be undertaken, including choosing a career. A process or activity of a person to prepare himself to enter a career that is related to work through a systematic process so that he can finally choose a career as expected is the definition of career choice (Dwi and Setiawan, 2012). In line with this definition, Savitri (2014) says that career choice is one part of a person's life journey in making choices that he will undergo through a long process namely internal factors that include physical limitations and appearance given since birth, personality, interests, talents, knowledge about the chosen career, needs, self-image, values in oneself about careers, and learning experiences. While external factors include family, "information about career, living environment. In Bandung, several students as resource persons in this study stated that work flexibility and work environment were indeed a consideration in choosing a job, but they still tended to be confused about choosing the right career. Therefore, researchers began to find out the perception they have about startups.

Perception is a cognitive process that individuals experience in understanding every information through the five senses, but basically something that is received by everyone is different from object realization (Prasetyo, et al, 2016). Events or things experienced by an individual will have a different response and perception from other individuals. Perception can be defined as the process of organizing and "interpreting sensory impressions" on individuals to give meaning to their surroundings (Robbins and Judge, 2015). This definition is like Lubis (2010) which states that perception is how people interpret events, objects, and humans. Walgito (2010) provides an opinion about perception where perception is a process that is initiated by sensing, which is a process of receiving stimulus to individuals through a sensory process. Perception has three indicators, including absorption of objects/stimuli from outside the individual, understanding of objects and assessment of objects (Walgito, 2010). Perceptions of everyone can differ from one another, as well as the perception of startups. Several economic and business students in Bandung who have been successfully interviewed have different perceptions, both positive and negative, towards startup companies. Some students have the perception that all startup companies are digital technology-based companies, besides that working at a company is startup considered very enjoyable because it is provided with adequate facilities, a modern environment, flexible time, also relaxed and free work, but regarding salary they have a perception that company salaries startup are low. The role of perception is very important in determining one's career choice (Sulistyawati, 2013), if generation $\mathrm{Y}$ and generation $\mathrm{Z}$ students have a misperception of companies, startup it is possible that one day they will be involved or choose a career in the world because startup they will not last long because of their high expectations. it is not in accordance with.

A positive perception will direct a person to the intended career choice. Such as research by Prasetyo (2016) which states that perception provides support for career choices in the field of taxation. This is in line with research conducted by Sari (2013) which concluded that in his research, perception has an influence on career choice as a public accountant. Mahayani (2017) also concludes that the perception variable influences career choice. Based on several previous research results, it can be said that perception and career choice have a relationship. Perceptions that exist in individuals vary from one to another. The relationship between variables, namely perceptions and career choices, which is supported by previous studies, shows that perceptions and career choices have a relationship, but there is no research that has examined perceptions and career choices in generation $\mathrm{Y}$ and generation $\mathrm{Z}$, especially in startups so that the purpose of this study is to researched and analyzed " The Influence of Perception Regarding Startup Towards Career Choices in Startup Field on Generation Y and Generation Z College Students in Bandung City". The hypothesis in this study is H0: perceptions of startups have no effect on 
career choices in the field startup; H1: Perceptions of startups affect career choices in the field startup.

\section{RESEARCH METHODS}

This study examines and analyzes a problem or phenomenon and explains the influence between variables, tests hypotheses and obtains the implications or meaning of the problems to be studied. The population in this study were economics and business students at ITB, UNPAD, UPI, UNPAR, UNPAS, UNISBA, and TEL-U. This type of research is quantitative with primary data collection techniques through questionnaires. Samples were taken by accidental sampling which is a technique of determining the sample spontaneously (Kusniawati, 2010). The number of samples refers to Hair et al (2014), namely the number of indicators (21) times 5, which is a minimum of 105. The samples in this study were divided into categories based on generation, namely generation $\mathrm{Y}$ and generation $\mathrm{Z}$, which according to Agung (2006) and Gall et al. (2007) to examine two or more categories, a minimum sample size of 15-30 people is required for each category/group. There were 168 respondents consisting of 72 respondents from generation $\mathrm{Y}$ and 96 respondents from generation $\mathrm{Z}$. The results of data collection were processed and analyzed using analysis tools Partial Least Square 3 (PLS).

Measurement of the validity and reliability of the data on SmartPLS seen from the outer model. Convergent validity and discriminant validity are used to measure validity while composite reliability and Cronbach's alpha are used to test the reliability (Hair, 2014). To determine the relationship and the significance of the variables seen from the value of the inner model ( $\mathrm{R}$ square and path coefficient). In hypothesis testing, the value of $\mathrm{t}$-statistics $>\mathrm{t}$-table will support the hypothesis where the t-table value in this study is 1.97. Analysis to measure the influence between variables based on generational grouping using PLS-MGA (Henseler, 2012).

\section{RESULTS AND DISCUSSION}

Based on the results of data collection, there were 168 samples consisting of $42.9 \%$ of generation Y and $9657.1 \%$ of generation $\mathrm{Z}$. Based on the level of education, respondents were dominated by the level of S1 education, namely 66\%, S2 32\%, and D3 2\%. In the outer model test, the test was convergent validity carried out twice after removing the indicators that had a value outer loading $<0.5$. The AVE value on the perception variable is 0.722 , and the career choice is 0.522 , which means that the AVE value on all variables is said to be good and the existing indicators can define the latent variable. In the reliability test, the value of composite reliability on the perception variable is 0.947 , and the career choice variable is 0.961 while Cronbach's alpha on the perception variable is 0.931 and career choice is 0.956 . The reliability test scores, namely composite reliability and Cronbach's alpha in this study, have met the requirements because all variables have a value $>0.7$. In this study, the R-value square of the career choice variable was 0.898 , meaning that the perception variable was able to explain the career choice variable of $89.8 \%$.

In testing the influence of perceptions about startups on career choices, it can be seen from the path coefficient in table 1 , while if viewed by group, namely generation $\mathrm{Y}$ and generation $\mathrm{Z}$, it can be seen in table 2 below. 
Table 1. Path Coefficient

\begin{tabular}{cccccc}
\hline & $\begin{array}{c}\text { Original } \\
\text { Sample (O) }\end{array}$ & $\begin{array}{c}\text { Sample } \\
\text { Mean } \\
(\mathbf{M})\end{array}$ & $\begin{array}{c}\text { Standard } \\
\text { Deviation } \\
\text { (STDEV) }\end{array}$ & $\begin{array}{c}\text { T Statistics } \\
(\mid \mathbf{O} / \text { STDEV|) }\end{array}$ & $\begin{array}{c}\text { P } \\
\text { Values }\end{array}$ \\
\hline $\begin{array}{c}\text { Perception -> Career } \\
\text { Choice }\end{array}$ & 0,492 & 0,507 & 0,168 & 2,933 & 0,003 \\
\hline
\end{tabular}

Table 2. Multigroup Analysis (MGA)

\begin{tabular}{|c|c|c|c|c|c|c|c|c|}
\hline \multirow[t]{2}{*}{ Relationship } & \multicolumn{2}{|c|}{$\begin{array}{c}\text { Path } \\
\text { Coefficients } \\
\text { Original }\end{array}$} & \multicolumn{2}{|c|}{ t-statistic } & \multicolumn{2}{|c|}{ p-values } & \multicolumn{2}{|c|}{ Conclusion } \\
\hline & Gen Y & Gen Z & Gen Y & Gen Z & Gen Y & Gen Z & Gen Y & Gen Z \\
\hline $\begin{array}{l}\text { Perception -> } \\
\text { Career options }\end{array}$ & 0,339 & 0,775 & 1,516 & 5,83 & 0,130 & 0,000 & $\begin{array}{c}\mathrm{H}_{1} \\
\text { rejected }\end{array}$ & $\begin{array}{c}\mathrm{H}_{1} \\
\text { received }\end{array}$ \\
\hline
\end{tabular}

Based on table 1, perception about startups affect the choice of a career in the field startup by 0.492 . The influence of perception on career choice is supported by the theory put forward by Walgito (2010) where the concept states that a person's perception will encourage behavior to determine a goal, where in this case the goal is to choose a career in the field startup. If students have a good perception of startups, then of course this will influence and encourage students' desire to have a career in the field startup, and vice versa. The perception of startups influencing career choices in the field startup is supported by research conducted by Sari (2013) which states that perception is one that can influence students' career choices, then. Mahayani's research (2017) also states that the perception variable about taxes influences career choices in the field of taxation. The group test, namely the $\mathrm{Y}$ generation group and the $\mathrm{Z}$ generation group seen in the MGA test, based on table 2, the perception of startups in generation $Y$ does not affect career choices in the startup field, while perceptions about startups in generation $\mathrm{Z}$ have a significant effect on career choices in the startup field. Perception s about startups encourage Generation $Z$ to have a career in the field startup, this can happen because Generation $\mathrm{Z}$ was born in an era of digital technology that has developed rapidly so that the growth of Generation $\mathrm{Z}$ is accompanied by their ability to master digital technology, which raises their interest in choosing a career in the field startup.

\section{CONCLUSION}

Based on the results of research and discussion, it is concluded that perceptions about startups affect career choices in the startup field for generations $\mathrm{Y}$ and $\mathrm{Z}$ in Bandung. When viewed from each generation group, in the generation $Y$ group the perception of startup has an influence on career choices in the startup field, while in the generation $\mathrm{Z}$ group the perception about startup has no effect on career choices in the startup field.

This research is expected to be a reference both from academics to provide material that can later be put into practice related to digital businesses, as well as from other parties such as startup actors by adjusting organizational rules to the characteristics of generation $\mathrm{Y}$ and generation $\mathrm{Z}$ such as flexible working hours and organizational structure, which is not so strict. In addition, research on the perceptions and career choices of Generation Y and Generation Z 
in the field is startup still very rarely done so that a more thorough development is still needed by adding variables, using other methodologies, or expanding the object of research.

\section{REFERENCES}

Agung, I Gusti Ngurah. 2006. Statistika Penerapan Model Rerata Sel Multivariat dan Model Ekonometri dengan SPSS. Jakarta: Yayasan SAD Satria Bhakti.

Ayu, R.K., 2017. Perempuan Pebisnis Startup di Indonesia dalam Perspektif Cybertopia. Jurnal Studi Komunikasi (Indonesian Journal of Communications Studies), 1(2).

Badan Ekonomi Kreatif (Bekraf). 2018. Mapping \& Database Startup Di Indonesia. MIKTI.

Bencsik, A., Horváth-Csikós, G., \& Juhász, T. 2016. Y and Z Generations at Workplaces. Journal of Competitiveness, 8(3).

Dwi, Christine., dan Setiawan Arif. 2012. Pengaruh Persepsi Mahasiswa Akuntansi Mengenai Lingkungan Kerja Auditor Terhadap Pilihan Karirnya Sebagai Auditor Di KAP (Studi Kasus pada Mahasiswa Akuntansi Universitas Kristen Maranatha dan Universitas Parahyangan). Jurnal Ilmiah Akuntansi, No. 08. ISSN: 2086-4159.

Gall, M., Gall, J.P., Borg, W.R. (2007). Educational Research: An Introduction (8th ed.). Boston, MA: Pearson.

Hair, Joseph, Jr et al. 2014. A Primer on Partial Least Squares Structural Equation Modelling (PLS-SEM). SAGE Publications, Inc. California, USA.

Kusniawati, Rina. (2010). Metode Penelitian: Penarikan Sampel Metode Penelitian.

Lubis, A. I. 2010. Akuntansi Keperilakuan. Jakarta : Salemba Empat.

Mahayani, N. M., Sulindawati, N. L., Herawati, N. T. 2017. Pengaruh Persepsi, Motivasi, Minat, Dan Pengetahuan Mahasiswa Akuntansi Program S1 Tentang Pajak Terhadap Pilihan Berkarir Dibidang Perpajakan. e-journal Nama Jurnal Universitas Pendidikan Ganesha, 7(1).

Nufus, A. 2017. Faktor Penentu Pemilihan Karir Siswa Smk Negeri 1 Dukuhuri Kabupaten Tegal. Skripsi. Fakultas Ilmu Pendidikan. Universitas Negeri Yogyakarta. 